\title{
'What does terrorism look like?': university lecturers' interpretations of their Prevent duties and tackling extremism in UK universities
}

Keith Spiller, Imran Awan and Andrew Whiting

Criminology Department, Birmingham City University, Birmingham, UK

\section{ABSTRACT}

The UK Counter Terrorism and Security Act (2015) (CTSA) calls for a partnership between the government, individuals, organisations and communities to prevent the radicalisation of individuals and to prevent their participation in terrorist and illegal activities. As part of this strategy, universities have a statutory duty placed upon them to remain vigilant to signs of extremism. Based upon 20 interviews with UK university lecturers, the paper examines reactions of the academic community to this governmental mandate. Key to our understanding is the deputisation of lecturers into a security regime and how they perform the duty of identifying and monitoring extremism. Equally, forms of resistance are evident in how lecturers understand their new roles and for universities themselves a conservative approach to risk may be gaining traction. We argue there is confusion around the CTSA based upon the ambiguous language in which it is presented and the conservative and defensive reactions that have subsequently produced concern amongst lecturers and UK universities. 
Pre-proof, to be published in the Journal of Critical Studies on Terrorism - not to be quote without permission

Introduction

In December 2016, we used the UK's Home Office counterterrorism e-learning training package. The package has been designed for public sector workers, including those working in universities, and guides users through a series of questions and possible answers. Presented are indicators that users can refer to when identifying 'What does Terrorism Look Like to You', and these in turn inform their vigilance and role in helping to combat terrorism in the UK (see Figure 1) (HM Government 2016). The initial questions in the package relate to the meaning of "terrorism"; then users are directed to the actual behaviours that might be a cause for concern, for example, "absenteeism", "crying" and "unhealthy use of the Internet" (see Figure 2). The suggestion is: if your students display these behaviours, then they may be in danger of extremism. Participating in this training prompted us to think about what university staff are being asked to do. Overlooking the disquiet we felt about viewing our students with suspicion, we were perplexed as to how we could identify a terrorist or terrorism? We also wondered: do other academics express similar reservations towards their counterterrorism duty and how does this new role impact on their university responsibilities? In this article, we examine how the academic community is reacting to its new-found security role. Framing our thoughts are the reactions of academics, as well as the challenges such strategies pose to the intellectual freedoms that underpin UK Universities.

The context to the article is the Counter Terrorism and Security Act 2015 (hereafter CTSA; http://www.legislation.gov.uk/ukpga/2015/6/contents/enacted), an act that was "fast-tracked" though Parliament (House of Lords, 2015) and one that mandates that "specified authorities" must engage with a counterterrorism strategy. As Theresa May - then Home Secretary - stated,

From 1 July the new statutory Prevent duty for specified authorities will commence. . . Once this has been fully implemented it will require local authorities, the police, prisons, probationservices, schools, colleges - and yes, universities too - to have due regard to the need to prevent people from being drawn into terrorism. . . This will ensure that Prevent activity is consistent across the country and in all those bodies that work with those who may be vulnerable. (Home Office 2014aa; emphasis added). 
Pre-proof, to be published in the Journal of Critical Studies on Terrorism - not to be quote without permission

\section{Figure 1. What does terrorism look like?}

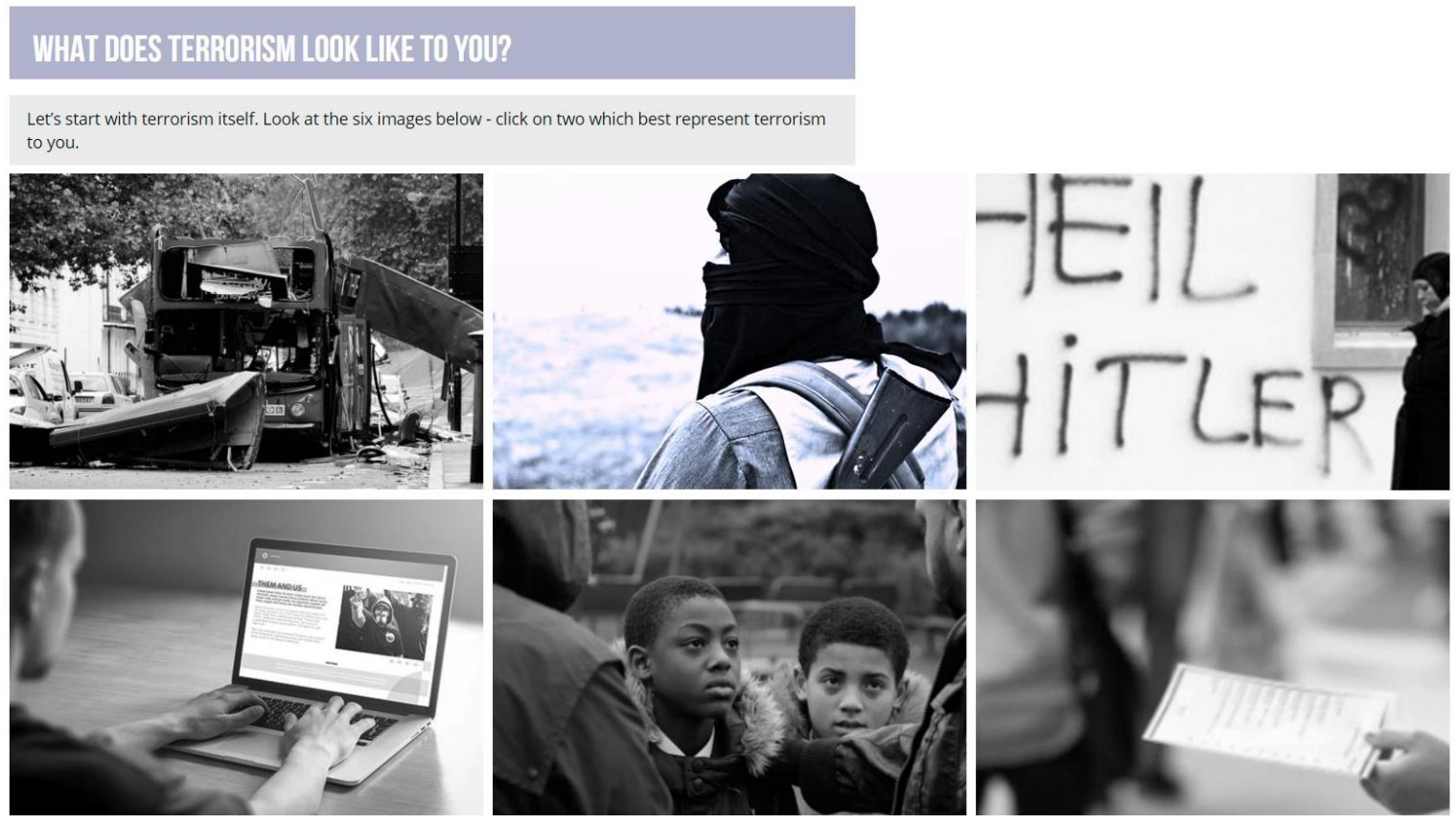

Figure 2. Behaviours that cause concern.

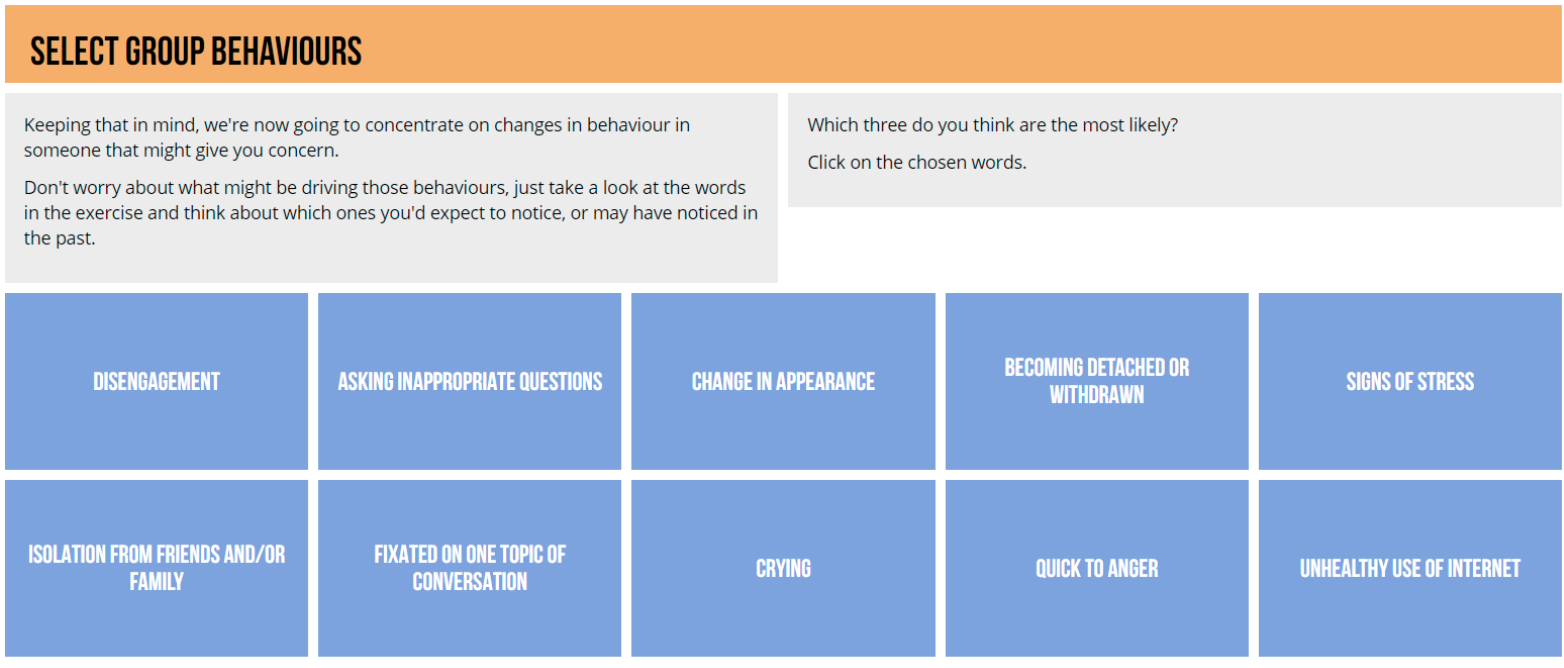

The CTSA effectively asks those in positions of authority to monitor those they supervise. We know monitoring has a significant effect on the subject (Ball 2009), and this is well covered by disciplines such as Surveillance Studies (Lyon, Haggerty, and Ball 2012). For example, previous work has investigated the surveillance of school children (McCahill and Finn 2010), employees (Ball 2010) and offenders (Nellis 2006). But what of the effects on those mandated to a national security regime? In 
Pre-proof, to be published in the Journal of Critical Studies on Terrorism - not to be quote without permission

recent times, neoliberal approaches and economy models favouring privatisation, de-regulation and fiscal austerity have been readily applied to security and this is evidenced through the wider spread of countering terror (see Heath-Kelly, Baker-Beall, and Jarvis 2015; Hoijtink 2014). The manner in which neoliberal values have also penetrated the field of education has helped to propel contentious issues arising from this new approach (see Baltodano 2012; Radice 2013) - for instance, unequal opportunities, an increasing audit culture, as well as the increasing educational and bureaucratic demands placed on academics (Mountz et al. 2015). More presciently the teaching of terrorism (and one could add other "controversial" subjects here) has received critical attention and has been assailed by the media and/or legislators for teaching terrorism in a biased form or the authorities' "heavy-handed" responses to using provocative materials. Accusations have included how UK universities propagate an anti-Semitic sentiment or the arrest and jailing of a university researcher for possessing a copy of an "Al Qaeda training manual" (Durodie 2016; Fitzgerald 2015; Miller, Mills, and Harkins 2011). These instances, and others, quite possibly curtail the resources and sources that staff are comfortable using when teaching terrorism. Indeed, monitoring for potential radicalisation may run counter to some of the established credentials of universities - as Theresa May seems to acknowledge with her comment ". . and yes, universities too". Not only does the CTSA challenge the premise of universities as places with a commitment to free speech, debate and knowledge creation, it may also serve to exacerbate the problems it is designed to prevent. As noted by Hillyard (1993) and Pantazis and Pemberton (2009), "hard" governmental approaches to countering terrorism often serve to boost recruitment to terrorist organisations. For example, tactics such as "stop and search" have led to about $1 \%$ of those stopped actually being arrested (Miller 2010). "Stop and Search" ultimately has served to hinder relations between police and local communities, and with this in mind, the CTSA may offer a comparable intervention (see Independent 2016).

Supporting students and ensuring their welfare is an expectation fairly placed on any university. Students do have a right to learn and grow in a safe environment. However, Channel Duty Guidance (the government's guideline on how to report suspicions behaviours) has identified 22 broad-ranging criteria that may indicate a student's likelihood to be drawn into terrorism. Lecturers are expected to report on:

- Feelings of grievance and injustice $\bullet$ Feeling under threat $\bullet$ A need for identity, meaning and belonging $\bullet$ A desire for status $\bullet$ A desire for excitement and adventure $\bullet$ A need to dominate and control others $\bullet$ Susceptibility to indoctrination - A desire for political or moral change • Opportunistic involvement - Family or friends involvement in extremism - Being at a transitional time of life $\bullet$ Being influenced or controlled by a group $\bullet$ Relevant mental health issues - Over-identification with a group or ideology • 'Them and Us' thinking • 
Pre-proof, to be published in the Journal of Critical Studies on Terrorism - not to be quote without permission

Dehumanisation of the enemy $\bullet$ Attitudes that justify offending $\bullet$ Harmful means to an end $\bullet$ Harmful objectives - Individual knowledge, skills and competencies - Access to networks, funding or equipment • Criminal Capability. (Channel 2012)

Such broad and ambiguous guidance is less than clear for those tasked with performing this newfound role. Indeed, prompting our initial thoughts towards the conception of this article were discussions we had had with colleagues at a departmental seminar on the consistency of Prevent training across the Higher Education (HE) sector, as well as how research or "science" was informing the guidance. The indicators, as outlined above, we contemplated lacked precision and secondary information was often required - for instance, knowing a student's family are "extremist". More significant perhaps is that the evidence-base that informs the guidance is less than obvious. In relation to universities, the CTSA does identify the need "to balance its legal duties in terms of both ensuring freedom of speech and academic freedom, and also protecting student welfare" (HM Government 2015, 4). Despite this, the UK's leading University and College Union attests that CTSA duties "seriously threatens academic freedom and freedom of speech" (see UCU 2015). These are contradictory and tension-filled statements that impact upon the academic community and have encouraged a climate of risk aversion. This, as we have discovered, can include impeding open debate, because panellists at university events are deemed "risky"; create reluctance to sanction research on certain topics; or highlight certain individuals because of styles of dress or facial hair. In what follows, the article progresses by first, reviewing the theoretical context that frames our conceptual approach, before presenting the empirical findings that have been taken from the interviews with university lecturers (hereafter we refer to teaching staff as lecturers; this includes all ranks and levels of university teachers). In the final section, the findings are discussed in relation to the CTSA, in particular, focusing on what we consider to be the adverse impact it is having across the entire academic community.

\section{Countering extremism}

Apparent within recent governmental initiatives have been the reactions of sovereign powers to the perceived threat of extremism and radicalisation - for example, responses to ISIS or even events such as the UK and France's interventions in Libya (Bakker and van Zuijdewijn 2015). Notably, these displays of sovereign power have tended to be rationalised by Western actors either explicitly through the discourse of the Global War on Terror, or in more recent years, moving away fromthis rhetoric and focusing on the threat posed by groups such as ISIS (Sekulow and Sekulow 2015; Schmitt 2016). Nevertheless, alongside these sovereign demonstration we have seen the extension of a less spectacular but still very significant form of power that has rapidly becomemore explicit in form and 
Pre-proof, to be published in the Journal of Critical Studies on Terrorism - not to be quote without permission

more widespread in focus, namely, state-led counter-terror interventions. In this way, agendas such as the CTSA succeed in coopting a wide array of institutions and specified authorities into conducting a counter extremism mandate. Throughout, a governmental power manifests "either directly through large scale campaigns, or indirectly through techniques that will make possible, without the full awareness of the people" (Foucault 1991: 100). In the example we cite, lecturers are deputised to monitor their charges for indications of extremism. Important to contextualising our perspective here is the monitoring and social control of "societies of strangers".

Works embedded in such perspectives have broadened understandings of some of the changing relationships of power, individuals and institutions (see Bauman 2000; DeLanda 2006; Stenson 2010). Organisations, institutions and governing authorities at all levels of scale rely on surveillant techniques to control risks associated with their activities (Clark 2008; Foucault 2001, 2007; Power 2004). Simply, without these bureaucratic functions, modern transactions and activities of all kinds would be difficult to perform and maintain (Beck 1992). However, the widespread application of these techniques has been posited to cause a number of socially dangerous consequences which stem from their ability to discriminate between different population groups within the domains of application. The ability to "socially sort" populations (Lyon 2001) into databases has real consequences for populations deemed risky (Vlcek 2007). Bureaucratic decisions can, and often do, result in varying levels of convenience, access to services, use of space and life chances (see Graham 2005; Surveillance Studies Network 2010).

In addition, there is an increasing array of individuals and organisations that perform risk analysis roles which are intended to limit harms, such as illegal movement of money, people or terrorism (Mueller and Stewart 2011). Deputised into these roles are "control workers" who make decisions about who may or may not pose a risk (see Rose 2000). Often performed through categorisation, as individuals or collections of individuals, these people are identified because they are viewed to be outside designated thresholds of acceptable risk (see Ericson and Haggerty 1997). Control workers are those tasked with monitoring the thresholds and breeches of these maxima; in turn, automated, algorithmic or human monitoring systems guide the decision-making towards what Gandy (2012) calls "cumulative" disadvantages.

Since 2001, there has been a growing prevalence of digital monitoring or reporting; for example, banks, car dealership or purveyors of high-end goods must report suspicious activity (Proceeds of Crime Act 2002). A blurring of the boundaries between those under the auspiciousness of the security services and those within the private sector has enjoyed a growing maturity (see Ball et al. 2015). Moreover, a pre-emptive agenda which targets risky activities, individuals or organisations using 
Pre-proof, to be published in the Journal of Critical Studies on Terrorism - not to be quote without permission

information harvested from multifarious sources is now standard practice in the UK. Mined data is a key source in identifying and countering threats (DeGoede 2008) and has engineered a new securitisation dependant on the collaboration of the private sector and governmental departments.

Reflecting these developments and as has been noted by recent work on security, is the rise of a neoliberal agenda which seeks to responsibilise non-state actors to perform security roles (Goold, Loader, and Thumala 2010; Loader and Walker 2010). Driving enquiry into these developments is a need for greater understanding of the new political economies of security (Huysmans 2011; White 2011). UK governmental initiatives, such as Prevent (2009) or Request a Check (see Home Office 2014) encourage non-traditional participation by enrolling "special" actors - who are in effect deputised to perform security. The deputisation is mandated through the legislation and actors, for example, designated staff - i.e. a Money Laundering Reporting Officer who must report suspicious activity (see Proceeds of Crime Act 2002). The Data Retention and Investigatory Powers Act (2016) is another example, where internet providers must retain the previous 12 months of customers online activity. The significance of these types of changes has been examined at state level (Adey 2012), and in relation to activities such as airline travel (Bennett 2005). Indeed, in a climate where increasingly nonsecurity specialist organisations are implicated in national security regimes, this is an important conceptual development in the impact and enrolment of university staff, as it poses questions about the political and indeed, labour expectations that the strategy demands.

Adding to this movement towards organisations playing a new security role is the impact of the mandate on those with new security responsibilities. It would appear the CTSA is producing a conservative effect on universities. What underscores this effect is deterrence (Penney 2016; Schauer 1978). For example, drivers are deterred from speeding because if caught they will face a fine or imprisonment; the penalty deters illegal activity. However, as Schauer (1978) is careful to point out, there is also a more benign element to deterrence, an inhibitory effect caused by, for example, infringing a person's will to express an opinion or act in otherwise legal contexts. The unease felt echoes Jackson's (2016) dilemma when recognising moments of "self-censor". Critical Terrorism Studies (CTS) scholars may accept invitations to government events, or may contribute to policy documents, because not doing so will limit opportunities to work with the state. This, as Jackson argues, "legitimates and perpetuates" the implementation of such strategies. Indeed, as researchers we are told we must be policy relevant and so by our acquiescence, we may sanction counter-terror systems rather than challenge or deconstruct them.

Alternatively, as Toros (2016) contends, there are still benefits to be had by sitting down with policymakers in expanding the input of the academic community. Ours is a challenge to governmental 
Pre-proof, to be published in the Journal of Critical Studies on Terrorism - not to be quote without permission

initiatives and our observations serve to highlight the complicity and resistance within the academic community that may be influencing the implementation of the CTSA. With the recognition that activities are surveilled, recorded and data-mined, a blanket of caution influences what is understood as risky - for example, Muslim-Americans viewing certain websites post 9/11 or the use of social media (see Marder et al. 2016; Sidhu 2011).

However, there may also be another important factor here and one that Scott (2013) calls "anarchist calisthenics", a concept that suggests people must practise small resistances often in order to be prepared for moments when bigger issues or resistances are needed. These resistances refer to lowlevel law-breaking, for example, "jaywalking" or crossing the road when it is clear and the red pedestrian light is showing. Such small disobediences help to erode the fear one may have to resist or make a stand against a law or a governmental position or civil order. Small resistances and "dragging one's feet" are a tentative form of protest with the potential to explode into greater forms of protest. Nevertheless, others have argued that the passivity of universities towards their adoption of governmental agendas and neoliberal approaches to both education and countering terrorism (Mountz et al. 2015; Radice 2013) aids the reach and acceptance of neoliberal policies and a continued drive for bureaucratically influenced betterment.

Academics have security responsibilities, yet the rules of engagement or how they are expected to act remain unclear. And so the ambiguity surrounding the Act heightens tensions and fears - which as we argue culminate in conservatism, anxieties and resistance around doing something culpable (see Favarel-Garrigues et al. 2011; Power 2004). Within universities, management and staff have started to take a risk-averse approach to activities deemed controversial (Gardella 2006). This, we argue, is a form of bureaucratic conservatism where university management limits potential for risk which in turn causes a ripple effect, where those subject to the conservatism restrict their expectations and behaviours (Palfreyman 2007). This, at times, has been coupled with policies that identify certain communities as "suspects" and the "other" (read the Muslim community), all of which intensifies a politic of fear (Mythen, Walklate, and Khan 2009; Allen 2010; Spalek 2010; Moosavi 2013). "Suspect community" and "risk" have promoted contentious stereotypes, which in turn have exacerbated community tensions around feelings of suspicion and stigmatisation (Awan 2012; Mythen and Walklate 2016).

Indeed, previous CTS work acknowledges a need for greater engagement with isolated and pilloried communities (see Breen Smyth 2007; Gunning 2009). However, our focus is on a community with no security agenda that is being asked to police "risk" groups (see Ericson and Haggerty 2007). Elements of the CTSA target Muslims and this may also be evident in the wider narratives of Muslims as being 
Pre-proof, to be published in the Journal of Critical Studies on Terrorism - not to be quote without permission

the new "folk devils" (Abbas 2005; Alam and Husband 2013; Awan and Zempi 2015). Islamophobia as a social construct not only results in hate crime victimisation, but it can be used to target groups who are deemed to be problematic (Copsey et al. 2013; Githens-Mazer and Lambert 2010). Recent literature on Islamophobia has been concerned with victimisation (Allen, Isakjee, and Young 2013; Littler and Feldman 2015; Meer 2010; Perry 2001; Taras 2012), and in educational literature there has been a focus on the stigmatisation of students and the impacts of security regimes on the identity and perceptions of Muslim students (see Kyriacou et al. 2017; Hopkins 2011). In contrast, our study makes the case that a new form of institutional targeting is now increasingly being adopted through state measures that do not necessarily only impact upon Muslim students, but also those tasked with new roles of monitoring. We argue that the CTSA duty on Universities impacts upon those from all backgrounds, religious beliefs and communities who are monitored, and importantly, have to monitor.

\section{Talking to lecturers}

The research that informs the article sets out to provide an initial and exploratory study into the specific nature of university lecturers' perceptions of their CTSA duty, with the focus placed on qualitative depth rather than volume of participants. To achieve this, we conducted

20 semi-structured interviews with university lecturers between April and November of 2016. While the CTSA duty has implications in HE wider than just lecturers, this study deliberately chose to focus on university lecturers due to the breadth of work they carry out, including teaching, supervision, research, organising and running academic events and administration. An initial group of 6 participants were selected purposively in the first instance to produce a small group that reflected diversity in academic discipline, geographical/ institutional location and gender. This was then snowballed (Silverman 2013) to include 20 participants that further diversified the sample. Participant's levels of seniority included lecturers, senior lecturers, associate professors/readers and professors. Moreover, the disciplinary spread included Criminology, Computer Sciences, Law, Education, Social Science, Business and Politics. The gender make-up of participants was 13 male and 7 female. The geographical range included participants from universities across the UK.

Given that the initial sampling technique was initially selective and subsequently expanded, we are not claiming that the findings can be generalised across $\mathrm{HE}$ or that the findings are exhaustive. Instead, the modest sample size reflects the exploratory nature of the study. However, the detail in which these interviews were conducted did mean that a sizeable amount of qualitatively rich data was generated (over $30 \mathrm{~h}$ of interviews). 
Pre-proof, to be published in the Journal of Critical Studies on Terrorism - not to be quote without permission

We acknowledge a more sizeable and random sample could draw out additional themes and perspectives and shed light on those academics with a more favourable interpretation of their duty. However, this is a theme we did not find and therefore should be explored in more substantive future work. After 20 interviews had been conducted, we considered the study "complete" insofar as new theoretical categories were not materialising (see Milliken 1999: 234). The interviews were conducted in a semi-structured manner with a series of scripted questions that each participant was asked in order to ensure a certain degree of consistency between interviews; but then, around these questions space was granted for further discussion and elaboration. Initial questions sought to:

- Determine if participants were aware of the Prevent Duty and the CTSA more generally;

- Establish how participants understood key terms in the CTSA;

- Examine participants' views on the University's role in tackling extremism;

- Document participant's views on their own individual role in tackling extremism.

Interviews were conducted face-to-face, over the phone, via email and using Skype. Interviews were recorded and transcribed so that the authors could discuss the findings and conduct a thematic analysis of the transcripts. We conducted this analysis as part of the ongoing and reflective process, where each author went through the transcripts to familiarise themselves with the entire data set before independently identifying themes and cross examining these with the findings of the other authors. After reviewing the interviews, we decided that a number of themes were sufficiently widespread across the transcripts that we organised our findings in relation to deputisation, resistance and bureaucratic conservativism.

\section{Working with the CTSA}

We themed our findings along three prominent topics: first, the deputisation of lecturers and the tensions evident in how they understand and accept their new responsibilities; second, resistance to the CTSA through small and mundane acts of disobedience committed by lectures' and third, bureaucratic conservatism and risk-averse interpretations understood and experienced by universities in relation to the CTSA. 
Pre-proof, to be published in the Journal of Critical Studies on Terrorism - not to be quote without permission

Deputisation

In our interviews, participants keenly identified a pressing tension to their CTSA roles, namely, an understanding of university as a place for the development and expressions of intellectual freedom, which for many academics runs counter to the CTSA mandate to monitor for suspicious behaviour. Pressing in the views of the lecturers was how the CTSA duty serves to undermine some of the core functions of the university. As one respondent put it:

. . Its [University's] primary function is about debate, conduct of research, producing and disseminating knowledge and also dissent I think is really important. Universities should be a space for speaking truth to power [. . . ] this kind of responsibility makes that far more difficult. (Politics, South East, Male)

As the lecturer suggests, being duty-bound to act upon signs of potential radicalisation is problematic, especially if it is viewed as curtailing academic freedoms (Lukianoff 2014) and intimating the topics students may feel comfortable discussing. The following participant continues in this vein:

If I was expected to engage in significant monitoring of students it is likely that they (or at least some groups) would consider me to be a member of the state (or at least university) apparatus and be significantly more suspicious of me and cautious of what could be said.

(Sociology, Yorkshire, Male)

Identifying as being a member of the state, or indeed as a "control worker", may run counter to how the lecturer views themselves; but it may also have the effect of limiting the expression of a student who dresses in a certain way or has a certain viewpoint. For the following participant, limiting freedoms of expressions is again of deep concern:

How can we build trust with our students when the very thing we are doing will create suspicion and mistrust? I am genuinely not sure now whether someone wearing a headscarf or if someone has a beard should warrant me contacting the relevant services. I mean that's worrying because it's not just me who thinks like this. I have had colleagues contact me and say to me is she someone who needs reporting because she wears a face veil and has said she had travelled to Turkey for a holiday. (Social Sciences, East Midlands, Female)

These comments highlight the unease surrounding a securitisation designed to maintain the safety of the UK, and beyond (Bausch and Zeitzoff 2015). Premised on much of the political mire of post 9/11, Iraq and now Syria, there is a deliberate and sustained focus on certain communities that have been deemed risky (Aradau and Van Munster 2007; Heath-Kelly 2013). The repercussions of such an 
Pre-proof, to be published in the Journal of Critical Studies on Terrorism - not to be quote without permission

approach often serve to make the targeted group feel isolated and labelled as different from host populations, with a limited effect on countering risk (see McGovern and Tobin 2010). In this instance, religious and political identity become targeted by association, and Choudhury and Fenwick (2011) attest that British Muslims and young British men in particular feel a sense of alienation and resentment towards CTSA programmes and counterterrorism legislation. Participants identified Muslim students as those who would ultimately bear the brunt of the mandate disseminated from government to the university, as well as extending the idea that "[c]ounter-terrorism measures are contributing to a wider sense among Muslims that they are being treated as a 'suspect community' and targeted by authorities simply because of their religion" (Choudhury and Fenwick 2011: 11; see also; Hickman et al. 2011).

An institution premised on producing knowledge and speaking "truth to power" that is being co-opted into a programme of state surveillance offers conflicts of interest - particularly when particular populations are being targeted. The approach deepens tensions of suspicion and mistrust, thus reducing the ability of staff and students to engage, debate and reflect on "controversial" or risky topics, a key premise to the ethos of universities to explore and foster knowledge (Kyriacou et al. 2017). However, equally pressing is a sense of "not knowing what to do" in the face of new-found requirements and the ambiguity as to how the CTSA is to be actioned:

...we didn't have a strategy as an institution to deal with it so we were feeling around in the dark a little bit about how best to respond to the concerns that had been raised to us as academic staff and I think we probably took quite a risk averse approach. . . and I'm not suggesting that's necessarily a bad thing but I think that until we see some clearer guidance or guidelines around the sort of strategy that we should be adopting as an institution I think there are potential dangers and there are potential consequences for students and their futures if we are too risk averse and how we respond to any concerns that are raised. (Criminology, East Midlands, Male)

Despite training programmes and extensive training initiatives by the Home Office, none of the participants we spoke to had undergone CTS training (something we return to later in the article). Consequently, a climate of uncertainty and unease prevails in how lecturers understand the roles they are expected to perform. In addition, the potential damage to student-lecturer relations and hindrances to freedom of expression or debate equally contribute to the discomfort expressed by participants. 
Pre-proof, to be published in the Journal of Critical Studies on Terrorism - not to be quote without permission

Resistance

The CTSA has added to staff workloads, ones that are often already stretched and overloaded (see Mountz et al. 2015), and this too may add to the reluctance of staff when engaging with the CTSA; not only are they unsure of what to do, but they are committed to other teaching, research and administrative tasks. As one participant identifies, there may be something dangerous about deputising underprepared staff:

. . Staff are just simply not qualified to do this, academic staff are not psychologists or psychiatrists, they're not counter-terrorist practitioners, they're frequently overworked and balancing multiple responsibilities. There is something particularly dangerous I think about asking staff to become involved in these kind of matters. (Politics, South East, Male)

Indeed, within the climate of neoliberal approaches to education, the increasing pressures and labours on academics, as well as security roles, expose the tentative and awkward reasoning lecturers apply to their new-found responsibilities. Ultimately, this is something they feel underprepared to accomplish, and the more forceful pressure of the "neoliberal university" takes precedent (see Ball 2012).

However, it is in these fractious moments where "little" resistances to the responsibilities of CTSA come to the fore. For many, the demands of the CTSA are beyond their role as educators: "I am not going to deal with [CTSA]. . I I will not report something, but if I know a person is going to plant a bomb, then yes, I will call the police" (Law, South East, Female). Echoing the everyday anarchist calls of Scott (2013), this lecturer is adamant they will not be reporting unless there is a clear and vibrant danger - something the auspiciousness of civil duty would motivate rather than the mandate of the CTSA. In addition, antipathy to responsiblisation focuses on threats to academic freedoms. The following participant elaborates:

I think people think very strongly about it, and I think, you know [University] has a reputation for being radical political place. I think it would totally undermine our sort of, core bits of our identity if we were suddenly trying to squash debate in that way. (Politics, South East, Female)

This comment, for us, presents an interesting overview of the role now sought within universities. The department in question was once celebrated for its radical views, and this refers back to its Marxist positioning in the 1970s and 1980s, which to some degree allowed it to challenge the more generalist political rhetoric of the time in the UK. The freedom to challenge and debate is viewed as a central component of the department's identity (Royed 1996) - an identity the CTSA is clearly challenging. 
Pre-proof, to be published in the Journal of Critical Studies on Terrorism - not to be quote without permission

Elsewhere, participants expressed that their CTSA duty would have a countering effect on initiating the role on lectures in securitising universities and those enrolled in them:

The question with a general policy statement like that is how will universities translate into practice and I'm sure you'll find that there are many different attitudes and approaches across different universities. You might get some that follow it quite slavishly, you might get some that pay lip service to it and don't really buy into the underlying ethos and you might get some that frankly don't pay any regard to it at all. (Law, Wales, Male)

Dismissing one's CTSA responsibilities or providing the minimum of effort when performing them, we contend, offers some perspective on how the resistances to it are being actualised. This is separate to the institutional responses of universities, as we will see below, but at the "coal-face" of where lectures meet and interact with students a principle of doing the bare minimum and not fully participating in what the CTSA demands may demonstrate the form of resistance most readily available to lectures - albeit one that has the potential to escalate into organised protest and disobedience.

\section{Bureaucratic conservatism}

For UK universities, a different approach may be apparent and here we draw on what we consider to be bureaucratic conservatism in UK Universities - a conservatism that stems from CTSA directives and influences the management of UK Universities, where universities have adopted a compliant position towards contentious issues. Focusing on this phenomenon, one participant commented that there is a "paranoia surrounding ongoing events within the university" (Sociology, West Midlands, Female), and that this has manifested itself in the form of growing amounts of paperwork: for example, external speakers must be fully vetted before attending the university. The process includes completing a form with details of the speaker, the topic of the talk and where and when it will take place. The form must be approved within the department and within the faculty. As a participant explains:

We tried to organise a conference and invited a number of guest speakers. However we had to fill in all these forms and once we completed them the University rejected our application. We were never told why except that the list of speakers and event I think was too sensitive, because it was about terrorism. . (Sociology, Midlands, Male)

Terrorism is undoubtedly a sensitive subject and one with challenging and probing issues. However, as this participant felt, if the subject matter is being restricted due to its sensitivity, then this is overtly 
Pre-proof, to be published in the Journal of Critical Studies on Terrorism - not to be quote without permission

effecting open debate and learning. The following participant speaks of the unease that has been injected into her supervisory relationship with a PhD student:

It... feels a bit awkward, for instance I have a Saudi PhD student and I always have to remind her that if she is going away, she has to notify the authorities, everything she needs to do she has got to ask permission in a way that other students don't. And I feel a bit apologetic about it and you know, a little bit like I am part of this system that doesn't trust her. It is quite minor. I certainly don't feel scared or suspicious of students I don't think. (Education, South West, Female)

To ensure compliance, the student is reminded of their obligations to register where they are. The participant may be doing this with good intent - i.e. not wanting the student to get in "trouble". However, as the participant notes, because this student is a non-European Economic Area (non-EEA) student they face greater scrutiny. Evident are sensations of awkwardness in performing the role assigned to the participant. The participant draws on trust and how the student is ultimately stigmatised due to their nationality, but more pressing here is how the participant acknowledges she is part of the system - a system she is clearly ill-at-ease with, but one she must be complicit with.

Another aspect of the PhD process is acquiring ethical clearance for research. The following participant talks about the difficulty associated with ethical approval for $\mathrm{PhD}$ research at their university since the CTSA duty came into effect:

Ethics reviews are more difficult doing this kind of research. But I guess it show ups the difficulties of ethical review processes, because if you are doing research on far right extremist websites that actually ethics is a constant negotiation rather than a review that happens at one point in time and then is kind of dealt with. I think it is also about the relationship with the person, so the student has a history of involvement in antiracist practice... So I guess it is about knowing the project I have and the risk of radicalisation through exposure to these spaces and I also think it is really important to have the freedom to go on these spaces and understand these space. Because how are you going to combat things like racism, it is important to understand how these ideologies are produced, how they circulate, how they are consumed. (Geography, Scotland, Male)

As the participant identifies, research (in particular, at postgraduate and post-doctoral levels) is aimed at producing "a contribution to knowledge", doing something original around a given topic. Hypersensitivity with regard to ethics committees as a result of the CTSA duty is not only problematic in how it could erect frustrating barriers preventing the undertaking of this sort of research, but is also 
Pre-proof, to be published in the Journal of Critical Studies on Terrorism - not to be quote without permission

potentially a counter-productive symptom of a university's interpretation of the duty imposed upon them (Pruzan 2016). In this instance, knowing the student, their history and the project is a clear feature in how the supervisor evaluates his participation in the project and this can be viewed in how risk is established and acted upon. The participant was also keen to suggest that without a history of anti-racist practice then the student may not have been looked upon favourably.

Impacts on the academic community

In moving towards a conclusion, we offer three points in expanding how we may begin to understand the impacts of CTSA in UK Universities. First, in thinking about deputisation, we borrow from Rose (2000) and Ericson and Haggerty (1997) in highlighting the role of the "control worker" - those with administrative authority that work to elevate risk and ensure sanctity. These workers are, in the first instance, the managers of universities that grant the presence of outside speakers or overview the ethical clearance of projects. It is they who are the overseer of the CTSA in universities. If there is any doubt to the sensitive nature of an activity, then it will face their scrutiny. This, we stress, refers to mundane and innocuous activities - such as student access to information, student debates, external speakers or researching particular topics deemed "sensitive". What prevails is an atmosphere of suspicion and fear towards certain research topics, particular events and communities. Participants highlight a fear that universities have embraced a process of self-discipline - one designed to avoid repercussions of adverse publicity a "sensitive" event may promote (see Guardian 2015). Consequently, there is a conservatism in how universities manage risk and how certain freedoms are understood.

Combined with this, the lecturer is also a "control worker" and this, we contend, is designed into the flows and events of life teaching in a university. In our institution, for instance, we are instructed to take a roll-call and record a student's presence or absence from lectures and seminars. Our conduct is shaped by an established logic of record keeping (cf. Caplan 2011). We already monitor students, we already record their absence. We categorise a student's presence and from this we infer a student's attitude, application or credentials. Much like the CTSA's 22 Framework, this can be used as an indicator of risk (Deleuze 1992). In this case, if absences prevail the student will be questioned or asked to leave. Policing through categorisation, as Ericson and Haggerty (1997) suggest, structures the actions and reactions of not just the police force, but multifarious actors, such as lecturers. This is achieved with regulations and socially accepted control measures. Decisions made, not just about the individual, but circumstantial categories surrounding the individual - where do they live, employment history, drug misuse, presence on electoral role, credit history, family circumstances - frame how we 
Pre-proof, to be published in the Journal of Critical Studies on Terrorism - not to be quote without permission

manage risk. It is no coincidence that credit is secured using many of the same categories (see Burton et al. 2004; Leyshon and Thrift 1999). The Home Office eLearning Figures that started this article alongside the 22 Framework are categories and framed responses that help "control workers" to make decisions. Yet, as our findings suggest, control workers remain confused on exactly what it is they have to do and why.

Second, there are varying degrees of resistance to the CTSA and these can take the form of university lectures "dragging their feet" when dealing with their new found security roles. These behaviours of ignoring the less than obvious, relying on common sense or "paying lip service" reflect low-level disobedience and irritation, as opposed to an outright refusal to fulfil the demands of the CTSA. Examples of more organised resistance are observable; open letters have been signed by academic experts and published in national newspapers (Guardian 2016) and as mentioned, the largest HE union has adopted an anti-Prevent stance. However, as far as we can ascertain, no major protest or objection has been lodged by university staff towards the CTSA, yet the comments presented here suggest how university staff are protesting in their own small ways.

Third, bureaucratic conservatism is a form of compliance and UK Universities have assumed a stance of practicality and efficiency when engaging with the CTSA. Take for example the many Prevent Groups now established in UK Universities, tasked with implementing counter-radicalisation and extremism agendas. The groups consist of a range of university staff, but are predominately management-led with an emphasis on: providing information and training to staff; producing and overseeing a protocol on the management of speakers and events; and managing the CTSA process among the student community. As Qurashi (2017) considers of his experiences in one such group, academic expertise is "side-lined" and there is little room for engagement with the authoritative position the CTSA demands of universities. As he suggests in citing ex-US Vice President Dick Cheney, it is not about analysis but about response to the situation. Absent is the critical voice of what the CTSA is asking the group to do; rather, the emphasis is on the practicality of ensuring the University attains the responsibilities placed upon it. Underscoring this approach, lecturers feel that universities are overly cautious in their interpretations of the CTSA. This, as we have suggested, may be due to perceived challenges on intellectual freedoms, but also evident is animosity to the defensive approaches taken by the universities. Undoubtedly, the education sector is not a homogenous entity and there is a range of responses from different institutions - not surprising given the lack of prescription handed down by the government. In fact, aspects of it have already been deemed not to apply to certain universities with Oxford and Cambridge debating societies both gaining exemption from the ban against "extremist speakers" (Espinoza 2015). 
Pre-proof, to be published in the Journal of Critical Studies on Terrorism - not to be quote without permission

Conclusion

To gain some clarity on the impact of the CTSA, we submitted a Freedom of Information (FOI) request to the Home Office. We asked for details on the amount of referrals made, how these referrals corresponded to the Channel assessment framework, did referrals lead to participation in deradicalisation programmes, and completion rates of university staff on CTSA training programmes. We learnt that 29,238 Higher Education/Further Education (HE/FE) staff (this includes any post-secondary school study towards a degree or a vocational qualification) have received training. Nevertheless, our other requests were declined on the basis of Section 22 and Section 36 of the Freedom of Information Act (see Supplemental data for the FOI). In the first instance, Section 22 refers to information that may be printed in the future, but no further detail was supplied - i.e. possible date of publication. Section 36 refers to the fact that releasing the information may prejudice the effective conduct of public affairs and there is a lack of public interest in the disclosure. The response lacked precision and certainly did not adequately answer our questions. This may be a continued reflection of the ambiguity of the CTSA message. Moreover, the amount of staff who have received training is limited. While 29,238 of all HE/FE staff may have participated in CTSA training, there are 201,380 academic staff and 208,750 nonacademic staff working in UK Universities alone (Universities UK 2017). The inconsistency of training across the sector will be a contributing factor when lecturers express their lack of knowledge when tasked with identifying radical behaviours, and this lack of knowledge exists while staff are bound by the CTSA mandate to monitor and report. However, this is not to say that more training represents the answer to all the issues raised here. While it may serve to increase lecturer's feelings of being more knowledgeable about the subject and in turn, their confidence identifying the signs of radicalisation, it does not address deeper issues within the knowledge base that informs the training (Lloyd and Dean 2015) - a significant problem that will be hard to overcome until all the research informing aspects like the ERG22 are published and debated (see Guardian 2016).

The CTSA is an expansion of state-led security into the educational sector and our goal has been to establish how lecturers understand their CTSA roles and to document their thoughts on the duty. Notwithstanding the threats posed by terrorism and the uncontroversial desire that the government has to prevent politically motivated violence against civilians, there are clearly concerns about the practical implications of making this a legal requirement to "inform" on students as potential extremists. In addition, institutions face a challenge to their renown for openness, tolerance and freedom of expression. Why a style of dress can be worrisome or why the topic of debate is reportable to government agencies, all remain deeply problematic to the lecturers we spoke to in UK Universities. Through formally enshrining this duty in law and deputising academic staff into a programme of state surveillance, the government risks breeding more suspicion between students and staff. Staff remain 
Pre-proof, to be published in the Journal of Critical Studies on Terrorism - not to be quote without permission

uncomfortable with the CTSA because they are being asked to act in a way that runs contrary to their understanding of what universities and expressions of intellectual freedoms, as well as creating an environment where staff with inadequate indicators are expected to monitor and report on suspicious behaviour.

The findings in this article concentrate on deputisation, resistance and bureaucratic conservatism, and these offer some semblance as to how we can begin to understand the effects of the CTSA in education. Universities must interpret the responsibility handed down to them and furthermore, university staff must make their own decisions as to how they carry out their duty (if at all). The CTSA has been accused of hindering opportunities to engage in open debate, restricting research around "sensitive" topics and creating a divide between staff and students. This is a counter-productive approach and one reminiscent of the heavy-handed government approaches of the past (see

Hillyard 1993). Moreover, lecturer's responsibilities have grown ever wider in terms of administration and pastoral care on top of their teaching and research. The CTSA adds security expectations upon these day-to-day duties. The argument here is not intended to highlight that lecturers are frequently spread thin across a range of diverse roles but, instead, that these extra statutory duties, a sense of ambiguity around the specifics of these duties and a questionable evidence base for them could in fact be dangerous as well as counter-productive. A void of comprehension poses a serious risk of defensive reporting as well as a disproportionate focus on suspect communities. Without adequate knowledge and skills lecturers are not equipped to conduct the work mandated upon them. More pressing, we would argue, the neoliberal approaches adopted by governments and universities towards security and education present a troubling perspective on how profit may override all else and indeed how open and critical debate is enjoyed. We contend much more detailed work is needed on how measures such as the CTSA impact on those living and working in UK society. 
Pre-proof, to be published in the Journal of Critical Studies on Terrorism - not to be quote without permission

References

Abbas, T., ed. 2005. Muslim Britain: Communities under Pressure. London and New York: Zed Books.

Adey, P. 2012. "Borders, Identification and Surveillance: New Regimes of Border Control." In Routledge Handbook of Surveillance Studies, edited by K. Ball, K. Haggerty, and D. Lyon, 193200. London: Routledge.

Alam, Y., and C. Husband. 2013. "Islamophobia, Community Cohesion and Counter-Terrorism Policies in Britain." Patterns of Prejudice 47 (3): 235. doi:10.1080/0031322X.2013.797779.

Allen, C. 2010. Islamophobia. London: Ashgate Publishing.

Allen, C., A. Isakjee, and O. Young. 2013. Understanding the Impact of Anti-Muslim Hate on Muslim Women. Birmingham: University of Birmingham.

Aradau, C., and R. Van Munster. 2007. “Governing Terrorism through Risk: Taking Precautions, (Un) Knowing the Future." European Journal of International Relations 13 (1): 89-115. doi:10.1177/ 1354066107074290.

Awan, I. 2012. “I'm a Muslim Not an Extremist:' How the Prevent Strategy Has Constructed a 'Suspect' Community." Politics \& Policy 40 (6): 1158-1185. doi:10.1111/j.1747-1346.2012.00397.x. Awan, I., and I. Zempi. 2015. "Virtual and Physical World Anti-Muslim Hate Crime." The British Journal of Criminology (Online). doi:10.1093/bjc/azv122.

Bakker, E., and J. D. R. van Zuijdewijn. 2015. “Jihadist Foreign Fighter Phenomenon in Western Europe: A Low-Probability, High-Impact Threat." The International Centre for Counter-Terrorism the Hague 6: 9.

Ball, K. 2009. "Exposure: Exploring the Subject of Surveillance." Information, Communication \& Society 12 (5): 639-657. doi:10.1080/13691180802270386.

Ball, K. 2010. “Workplace Surveillance: An Overview.” Labor History 51 (1): 87-106. doi:10.1080/ 00236561003654776.

Ball, K., A. Canhoto, E. Daniel, S. Dibb, M. Meadows, and K. Spiller. 2015. The Private Security State?: 
Pre-proof, to be published in the Journal of Critical Studies on Terrorism - not to be quote without permission

Surveillance, Consumer Data and the War on Terror. Copenhagen: Copenhagen Business School Press.

Ball, S. J. 2012. "Performativity, Commodification and Commitment: An I-Spy Guide to the Neoliberal University." British Journal of Educational Studies 60 (1): 17-28. doi:10.1080/ 00071005.2011 .650940$.

Baltodano, M. 2012. "Neoliberalism and the Demise of Public Education: The Corporatization of Schools of Education. International." Journal of Qualitative Studies in Education 25 (4): 487-507. doi:10.1080/09518398.2012.673025.

Bauman, Z. 2000. Liquid Modernity. Cambridge: Polity.

Bausch, A. W., and T. Zeitzoff. 2015. "Citizen Information, Electoral Incentives, and Provision of Counter-Terrorism: An Experimental Approach." Political Behavior 37 (3): 723-748. doi:10.1007/ s11109-014-9289-x.

Beck, U. 1992. "From Industrial Society to the Risk Society: Questions of Survival, Social Structure and Ecological Enlightenment." Theory, Culture \& Society 9 (1): 97-123. doi:10.1177/ 026327692009001006.

Bennett, C. 2005. "What Happens When You Book an Airline Ticket? The Collection and Processing of Passenger Data Post 9/11." In Global Surveillance and Policing, edited by E. Zureik and M. Salter, 113-127. Portland: Wilan.

Breen Smyth, M. 2007. "A Critical Research Agenda for the Study of Political Terror." European Political Science 6 (3): 260-267.

Burton, D., D. Knights, A. Leyshon, F. C. Alferof, and P. Signoretta. 2004. “Making a Market: The UK Retail Financial Services Industry and the Rise of the Complex Sub-Prime Credit Market." Competition and Change 8 (1): 3-26. doi:10.1080/1024529042000269806.

Caplan, J. 2011. "The Administration of Gender Identity in Nazi Germany." History Workshop Journal 72: 171-180. doi:10.1093/hwj/dbr021. 
Pre-proof, to be published in the Journal of Critical Studies on Terrorism - not to be quote without permission

Channel. 2012. "Vulnerability Assessment Framework". Accessed 24 September 2016. http://course. ncalt.com/Channel_General_Awareness/01/resources/docs/vul-assessment.pdf.

Choudhury, T., and H. Fenwick 2011. "The Impact of Counter-Terrorism Measures on Muslim Communities." Equality and Human Rights Commission Research Report 72. Accessed 20 June 2016. http://www.equalityhumanrights.com/uploaded_files/research/counter-terrorism_ research_report_72.pdf.

Clark, S. 2008. "Privacy and National Identity Cards: A Legal and Technical Study, Australia and the New Technologies: Evidence Based Policy in Public Administration." Accessed 20 June 2016. http:// works.bepress.com/cgi/viewcontent.cgi?article=1092\&context=kmichael\&referer=www.click find.com. au\#page $=225$.

Copsey, N., J. Dack, M. Littler, and M. Feldman. 2013. Anti-Muslim Hate Crime and the Far Right. Teeside: Teeside University.

DeGoede, M. 2008. "Beyond Risk: Premediation and the Post-9/11 Security Imagination." Security Dialogue 39 (2-3): 155-176. doi:10.1177/0967010608088773.

DeLanda, M. 2006. A New Philosophy of Society: Assemblage Theory and Social Complexity. London: Continuum.

Deleuze, G. 1992. "Postscript on the Societies of Control." October 59, 3-7.

Durodie, B. 2016. "Securitising Education to Prevent Terrorism or Losing Direction?" British Journal of Educational Studies 64 (1): 21-35. doi:10.1080/00071005.2015.1107023.

Ericson, R. V., and K. D. Haggerty. 1997. Policing the Risk Society. Oxford: OUP. Espinoza, J. 2015. “Oxford and Cambridge Debating Societies Escape Ban on Extremism." The Telegraph, Accessed 16 March 2015. http://www.telegraph.co.uk/education/universityeduca tion/student-life/11471654/Oxford-and-Cambridge-debating-societies-escape-ban-on-extre mism.html.

Favarel-Garrigues, G., T. Godefroy, and P. Lascoumes. 2011. "Reluctant Partners? Banks in the Fight 
Pre-proof, to be published in the Journal of Critical Studies on Terrorism - not to be quote without permission

against Money Laundering and Terrorism Financing in France." Security Dialogue 42 (2): 179_

196. doi:10.1177/0967010611399615.

Fitzgerald, J. 2015. "Why Me? An Autoethnographic Account of the Bizarre Logic of

Counterterrorism." Critical Studies on Terrorism 8 (1): 163-180. doi:10.1080/

17539153.2015.1005934.

Foucault, M. 1991. “On Governmentality.” Ideology and Consciousness 6: 5-22.

Foucault, M. 2007. Security, Territory, Population: Lectures at the College De France. New York:

Picador.

Foucault, M. 2001. “Power/Knowledge.” In The New Social Theory Reader: Contemporary Debates, edited by S. Seidman and J. C. Alexander, 69-76. New York: Routledge.

Gandy, O. H. 2012. Coming to Terms with Chance: Engaging Rational Discrimination and Cumulative Disadvantage. London: Ashgate Publishing.

Gardella, T. M. 2006. "Beyond Terrorism: The Potential Chilling Effect on the Internet of Broad Law Enforcement Legislation.” John's L Reviews 80: 655.

Githens-Mazer, J., and R. Lambert. 2010. Islamophobia and Anti-Muslim Hate Crime: A London Case Study. Exeter: University.

Goold, B., I. Loader, and A. Thumala. 2010. “Consuming Security? Tools for a Sociology of Security Consumption." Theoretical Criminology 14 (3): 3-30. doi:10.1177/1362480609354533.

Graham, S. D. N. 2005. "Software-Sorted Geographies." Progress in Human Geography 29 (5): 562580. doi:10.1191/0309132505ph568oa.

Guardian. 2015. “Mohammed Emwazi’s University Suspends All 'Sensitive' Events.” The Guardian, Accessed 27 February 2015. https://www.theguardian.com/education/2015/feb/27/ mohammed-emwazi-university-westminster-refuses-to-cancel-preacher-talk-islamic-society. Guardian. 2016. “Anti-Radicalisation Strategy Lacks Evidence Base in Science.” The Guardian. Accessed 29 September 2016. https://www.theguardian.com/politics/2016/sep/29/anti-radicali 
Pre-proof, to be published in the Journal of Critical Studies on Terrorism - not to be quote without permission

sation-strategy-lacks-evidence-base-in-science.

Gunning, J. 2009. "Social Movement Theory and the Study of Terrorism." In Critical Terrorism Studies, A New Research Agenda, edited by R. Jackson, M. Breen Smyth, and J. Gunning, 1333. Oxford: Routledge.

Heath-Kelly, C. 2013. “Counter-Terrorism and the Counterfactual: Producing the 'Radicalisation' Discourse and the UK PREVENT Strategy." The British Journal of Politics and International Relations 15 (3): 394-415. doi:10.1111/j.1467-856X.2011.00489.x.

Heath-Kelly, C., C. Baker-Beall, and L. Jarvis. 2015. “Editors' Introduction: Neoliberalism And/As Terror." Critical Studies on Terrorism 8 (1): 1-14. doi:10.1080/17539153.2015.1009761.

Hickman, J., L. Thomas, S. Silvestri, and H. Nickels, 2011. "Suspect Communities: Counter-Terrorism Policy, the Press and the Impact on Irish and Muslim Communities in Britain." Accessed 9 January 2017. http://www.statewatch.org/news/2011/jul/uk-london-met-suspectcommunitiesfindings.

pdf.

Hillyard, P. 1993. Suspect Community: People's Experience of the Prevention of Terrorism Acts in Britain. London: Pluto Press.

HM Government. 2015. “Prevent Duty Guidance: For Higher Education Institutions in England and Wales." Accessed 12 November 2017. https://www.gov.uk/government/uploads/system/ uploads/attachment_data/file/445916/Prevent_Duty_Guidance_For_Higher_Education_ England_Wales_.pdf

HM Government. 2016. “Prevent E-Learning Package.” Accessed 20 August 2016. https://www. elearning.prevent.homeoffice.gov.uk/ Hoijtink, M. 2014. “Capitalizing on Emergence: The 'New' Civil Security Market in Europe." Security Dialogue 45 (5): 458-475. doi:10.1177/0967010614544312.

Home Office. 2014. Request a Check. Accessed 20 August 2016 https://eforms.homeoffice.gov.uk/ 
Pre-proof, to be published in the Journal of Critical Studies on Terrorism - not to be quote without permission

outreach/righttowork.ofml.

Home Office. 2014a. "Home Secretary Theresa May on Counter-Terrorism." Accessed 24 November 2014.

https://www.gov.uk/government/speeches/home-secretary-theresa-may-on-

counterterrorism.

Hopkins, P. 2011. "Towards Critical Geographies of the University Campus: Understanding the Contested Experiences of Muslim Students." Transactions of the Institute of British Geographers 36 (1): 157-169. doi:10.1111/tran.2010.36.issue-1.

House of Lords/House of Commons Joint Committee on Human Rights. 2015. "Legislative Scrutiny: Counter-Terrorism and Security Bill." Fifth Report of Session 2014-2015, Accessed 20 August 2016. http://www.publications.parliament.uk/pa/jt201415/jtselect/jtrights/86/86.pdf. Huysmans, J. 2011. "What's in an Act? On Security Speech Acts and Little Security Nothings." Security Dialogue 42 (4/5): 371-383. doi:10.1177/0967010611418713.

Independent. 2016. "New Counter-Extremism Strategy Could Make Fight Even Harder." MPs warn. Accessed July 21 2016. http://www.independent.co.uk/news/uk/politics/counter-extremism-pre vent-strategy-could-make-fight-even-harder-a7149351.html.

Jackson, R. 2016. "To Be or Not to Be Policy Relevant? Power, Emancipation and Resistance in CTS Research." Critical Studies on Terrorism 9 (1): 120-125. doi:10.1080/17539153.2016.1147771. Kyriacou, C., R. Szczepek, B. Beatrice, F. Said, and I. Davies. 2017. “British Muslim University Students' Perceptions of Prevent and Its Impact on Their Sense of Identity." Education, Citizenship and Social Justice 12 (2): 97-110. doi:10.1177/1746197916688918. Leyshon, A., and N. Thrift. 1999. "Lists Come Alive: Electronic Systems of Knowledge and the Rise of Credit-Scoring in Retail Banking." Economy and Society 28 (3): 434-466. doi:10.1080/ 03085149900000013.

Littler, M., and M. Feldman. 2015. Tell MAMA Reporting 2014/2015: Annual Monitoring, Cumulative Extremism, and Policy Implications. Teesside: Teesside University Press. 
Pre-proof, to be published in the Journal of Critical Studies on Terrorism - not to be quote without permission

Lloyd, M., and C. Dean. 2015. "The Development of Structured Guidelines for Assessing Risk in Extremist Offenders." The Journal of Threat Assessment and Management 2 (1): 40-52. doi:10.1037/tam0000035.

Loader, I., and N. Walker. 2010. Civilising Security. Cambridge: Cambridge University Press.

Lukianoff, G. 2014. Freedom from Speech. New York: Encounter Books.

Lyon, D. 2001. Surveillance Society: Monitoring Everyday Life. Buckingham: Open University Press.

Lyon, D., K. D. Haggerty, and K. Ball. 2012. Introducing Surveillance Studies. Routledge Handbook of Surveillance Studies, 1-12. London: Routledge.

Marder, B., A. Joinson, A. Shankar, and D. Houghton. 2016. “The Extended 'Chilling' Effect of Facebook: The Cold Reality of Ubiquitous Social Networking." Computers in Human Behavior 60: 582-592. doi:10.1016/j.chb.2016.02.097.

McCahill, M., and R. Finn. 2010. "The Social Impact of Surveillance in Three UK Schools: "Angels", "Devils" and "Teen Mums." Surveillance and Society 7 (3/4): 273-289.

McGovern, M., and A. Tobin 2010. “Countering Terror or Counter-Productive: Comparing Irish and British Muslim Experiences of Counter-Insurgency" Law and Policy, Report of a Symposium held in Cultúrlann McAdam Ó Fiaich, Falls Road, Belfast. 23-24 June 2009.

Meer, N. 2010. Citizenship, Identity and the Politics of Multiculturalism: The Rise of Muslim Consciousness. New York, NY: Palgrave Macmillan.

Miller, D., T. Mills, and S. Harkins. 2011. "Teaching about Terrorism in the United Kingdom: How It Is Done and What Problems It Causes." Critical Studies on Terrorism 4 (3): 405-420. doi:10.1080/ 17539153.2011.623416.

Miller, J. 2010. "Stop and Search in England: A Reformed Tactic or Business as Usual?" British Journal of Criminology 50 (5): 954-974. doi:10.1093/bjc/azq021.

Milliken, S. 1999. "The Study of Discourse in International Relations: A Critique of Research and Methods." European Journal of International Relations 5 (2): 225-254. doi:10.1177/ 
Pre-proof, to be published in the Journal of Critical Studies on Terrorism - not to be quote without permission

1354066199005002003.

Moosavi, L. 2013. "Islamophobia in the Representations of Islam and Muslims by the British Government between 2001 and 2007." Turkish Journal of Sociology 27 (3): 33-368.

Mountz, A., A. Bonds, B. Mansfield, J. Loyd, J. Hyndman, M. Walton-Roberts, and W. Curran. 2015. "For Slow Scholarship: A Feminist Politics of Resistance through Collective Action in the Neoliberal University." ACME: An International Journal for Critical Geographies 14 (4): 1235-1259. Mueller, J., and M. G. Stewart. 2011. Terror, Security, and Money: Balancing the Risks, Benefits, and Costs of Homeland Security. Oxford: Oxford University Press.

Mythen, G., and S. Walklate. 2016. "Counterterrorism and the Reconstruction of (In) Security: Divisions, Dualisms, Duplicities." British Journal of Criminology 56: 1107-1124. doi:10.1093/bjc/ azw030.

Mythen, G., S. Walklate, and F. Khan. 2009. “I'm a Muslim, but I'm Not a Terrorist': Victimization, Risky Identities and the Performance of Safety." The British Journal Of Criminology 49: 736-754. doi:10.1093/bjc/azp032.

Nellis, M. 2006. "Surveillance, Rehabilitation, and Electronic Monitoring: Getting the Issues Clear." Criminology \& Public Policy 5 (1): 103-108. doi:10.1111/cpp.2006.5.issue-1.

Palfreyman, D. 2007. “Is Academic Freedom under Threat in UK and US Higher Education?” Education and the Law 19 (1): 19-40. doi:10.1080/09539960701231207.

Pantazis, C., and S. Pemberton. 2009. "From the 'Old' to the 'New' Suspect Community Examining the Impacts of Recent UK Counter-Terrorist Legislation." British Journal of Criminology 49 (5): 646-666. doi:10.1093/bjc/azp031.

Penney, J. 2016. “Chilling Effects: Online Surveillance and Wikipedia Use." Berkeley Technology Law Review 31 (1): 118-182.

Perry, B. 2001. In the Name of Hate: Understanding Hate Crimes. London: Routledge.

Power, M. 2004. The Risk Management of Everything: Rethinking the Politics of Uncertainty. London: 
Pre-proof, to be published in the Journal of Critical Studies on Terrorism - not to be quote without permission

Demos.

Pruzan, P. 2016. Research Methodology: The Aims, Practices and Ethics of Science. New York: Springer International Publishing.

Qurashi, F. 2017. "Just Get on with It: Implementing the Prevent Duty in Higher Education and the Role of Academic Expertise." Education, Citizenship and Social Justice, First Online.

Radice, H. 2013. ““'How We Got Here: UK Higher Education under Neoliberalism. ACME: An International2." Journal for Critical Geographies 12 (2): 407-418.

Rose, N. 2000. "Government and Control." British Journal of Criminology 40 (2): 321-339. doi:10.1093/bjc/40.2.321.

Royed, T. J. 1996. "Testing the Mandate Model in Britain and the United States: Evidence from the Reagan and Thatcher Eras." British Journal of Political Science 26 (01): 45-80. doi:10.1017/ S0007123400007419.

Schauer, F. 1978. "Fear, Risk and the First Amendment: Unraveling the Chilling Effect." Boston University Law Review 58: 685.

Schmitt, E. 2016. "US Scrambles to Contain Growing ISIS Threat in Libya." The New York Times, 21 Febrary. https://www.nytimes.com/2016/02/22/world/africa/us-scrambles-to-contain-growingisisthreat-in-libya.html?_r=0.

Scott, J. C. 2013. Two Cheers for Anarchism: Six Easy Pieces on Autonomy, Dignity, and Meaningful Work and Play. Princeton: Princeton University Press.

Sekulow, J., and J. Sekulow. 2015. Rise of ISIS: A Threat We Can't Ignore. New York: Simon and Schuster.

Sidhu, D. S. 2011. "The Chilling Effect of Government Surveillance Programs on the Use of the Internet by Muslim-Americans." University of Maryland Law Journal of Race, Religion, Gender and Class 7 (2): 375-393.

Silverman, D. 2013. Doing Qualitative Research: A Practical Handbook. London: Sage. 
Pre-proof, to be published in the Journal of Critical Studies on Terrorism - not to be quote without permission

Spalek, B. 2010. “Community Policing, Trust, And Muslim Communities In Relation To 'New

Terrorism'." Politics \& Policy 38 (4): 789-815.

Stenson, K. 2010. "Risk, Crime and Governance." In Transnational Criminology, edited by M. HerzogEvans. Nijmegen: Wolf Legal Publishers.

Surveillance Studies Network. 2010. An Update to a Report on the Surveillance Society UK Information Commissioner. Wilmslow: Information Commissioner's Office.

Taras, R. 2012. Xenophobia and Islamophobia in Europe. Edinburgh: Edinburgh University Press.

Toros, H. 2016. "Dialogue, Praxis and the State: A Response to Richard Jackson." Critical Studies on Terrorism 9 (1): 126-130. doi:10.1080/17539153.2016.1147775.

Universities UK. 2017. "Universities in Numbers". Accessed 2 February 2017 http://www.universitie suk.ac.uk/facts-and-stats/Pages/higher-education-data.aspx.

University and College Union. 2015. "The Prevent Duty: A Guide for Branched and Members".

Accessed 20 June 2016. https://www.ucu.org.uk/media/7370/The-prevent-duty-guidanceforbranches-

Dec-15/pdf/ucu_preventdutyguidance_dec15.pdf.

Vlcek, W. 2007. "Surveillance to Combat Terrorist Financing in Europe: Whose Liberty, Whose Security." European Studies 16 (1): 99-119.

White, A. 2011. "The New Political Economy of Private Security." Theoretical Criminology 16 (1): 85101. doi:10.1177/1362480611410903. 